\title{
Metacognitive Strategies and Learners' Attitudes: Evidence of Collocations
}

\author{
Gholamreza Abbasian \\ Imam Ali \& IA (South Tehran Branch) Universities, Tehran, Iran \\ PO Box: 17156-64691, Tehran, Iran \\ Tel: 98-935-305-9840Ｅ-mail: gabbasian@ gmail.com
}

Ali Mohammadi Darabad (Corresponding author)

PhD Candidate in TEFL, Islamic Azad University, South Tehran Branch, Tehran, Iran

Faculty Member of Amin Police University, Tehran, Iran

PO Box 13518 - 57195, Tehran, Iran

Tel: 98-912-707-0951Ｅ-mail: Mohammadi.ali741@gmail.com

Mehdi Javid

PhD Candidate in TEFL, Islamic Azad University, South Tehran Branch, Tehran, Iran

Faculty Member, Amin Police University, Tehran, Iran

PO Box: 17156-64691, Tehran, Iran

Tel: 98-935-305-9840Ｅ-mail: mjavid57@yahoo.com

Received: March 7, 2016 Accepted: April 5, 2016 Published: April 8, 2016

doi:10.5296/ijele.v4i1.9280 URL: http://dx.doi.org/10.5296/ijele.v4i1.9280

\begin{abstract}
The present study investigates the mediating role of attitude towards English language and the effect of metacognitive vocabulary learning strategy instruction on the recall of collocations. To this end, 75 upper-intermediate EFL participants reflecting positive and negative attitudes ( $+\mathrm{A}$ and $-\mathrm{A}$ ) based on Attitude/Motivation Test Battery) towards language were randomly assigned into two control and experimental groups. They both received the same type of collocation instruction, but the experimental group, additionally, received the
\end{abstract}


metacognitive explicit strategy instruction. A pretest and a posttest measuring the learners' collocation knowledge before and after treatment were administered. A two-way ANOVA was run to compare the two groups plus the effect of language attitude on such performance. The results indicated that treatment did have an effect on the recall of collocations and also the $+\mathrm{A}$ learners outperformed their -A counterparts.

Keywords: Attitude, Metacognitive strategies, Explicit strategy instruction, Collocation

\section{Introduction}

Contrary to many discussions about learning a second/foreign language which focus on the efficacy of teaching methodologies, little emphasis is given to the contextual factors individual, social and societal - e.g., possibly affecting Azeri-Turkish-speaking students' learning. These contextual factors can be considered from the perspectives of the language, the learner and the learning process.

Linguistically, these can be language distance between Turkish (SOV) and English (SVO), native language proficiency, and knowledge of the second/foreign language, and language status. From the learner's, the factors affecting language learning can be declared as various needs and goals, peer groups, starting age for language learning, pre-school support, and language attitudes. Psychologically speaking, the factors influencing language learning process can be outlined as learning styles and strategies, motivation, and classroom interaction (Walqui, 2000).

In this vein, language learners' attitude towards foreign language can be a determining factor, which has been investigated along with other variables influencing the outcome of a teaching-learning process. There is a great amount of research on attitudes towards different languages (Balcazar, 2003; Marley, 2004), towards different varieties of English and other languages (Assaf, 2001; Gibb, 1999; Karstadt, 2002; Starks \& Paltridge, 1994; Zhou, 2002), and on learners' beliefs about language learning (Sakui \& Gaies, 1999).Furthermore, language learning process has social and psychological aspects besides the cognitive approach. Attitude can be viewed from these three dimensions. Each one of these dimensions has different features to bring out language attitude results. Accordingly, the attitude has three components: behavioral, cognitive and affective. These three attitudinal aspects are based on the three theoretical approaches of behaviorism, cognitivism and humanism, respectively. The behavioral aspect of attitude deals with the way one behaves and reacts in particular situations. In fact, the successful language learning enhances the learners to identify themselves with the native speakers of that language and acquire or adopt various aspects of behaviors which characterize the members of the target language community.

Cognitive aspect of attitude involves the beliefs of the language learners about the knowledge that they receive and their understanding in the process of language learning. The cognitive attitude can be classified into four steps of connecting the previous knowledge and the new one, creating new knowledge, checking new knowledge, and applying the new knowledge in many situations. 
Regarding emotional aspect of attitude, Feng and Chen (2009) considered learning process as an emotional process. They believe that learning is affected by different emotional factors. The teacher and his students engage in various emotional activities in it and varied fruits of emotions are obtained. According to Choy and Troudi (2006), attitude can help the learners to express whether they like or dislike the objects or surrounding situations. It is agreed that the inner feelings and emotions of FL learners influence their perspectives and their attitudes towards the target language.

Different aspects of language attitudes have also been studied such as the relation between attitudes and motivation (Bernaus et al., 2004; Schmidt et al., 2004; Williams et al., 2002), the relationship between attitudes and learning strategies (Gan, 2004), the relationship between attitudes and level of achievement (Graham, 2004), beliefs and attitudes about target language use, first language use and anxiety (Levine, 2003), attitudes to language and language learning at secondary and tertiary levels (Yang \& Lau, 2003), attitudes towards English-language usage among peers (White, 2002), the relationship between negative attitudes towards non-native speakers and poor comprehension of those speakers (Lindemann, 2002), attitudes towards debatable usages between teachers and their students (Lee, 2001a), attitudes of English native and non-native teachers towards disputable usages (Lee, 2001b), the relationship between attitudes towards ideology, culture, people, language and factors affecting attitude (Flaitz, 1988). Popham (2011) argues that the reason for strengthening learners' positive attitudes and interests towards learning the language is that students, who gain positive attitudes towards present learning, will be inclined to follow learning later on. Kiptui and Mbugua (2009) demonstrated that negative mentality towards English was the most effective psychological factor that brought about the poor performance of students in English learning. Kara (2009) said that attitudes towards learning besides opinions and beliefs have an obvious effect on students' behaviors and therefore on their performance. In fact, the majority of the inquiries about the subject have reasoned that students' attitude is a necessary piece of learning and that it ought to turn into a key part of language learning and teaching methods.

Attitude has been defined variously. Triandis (1971) defines it as having a manner of consistency towards an object. Some scholars such as Kırımsoy (1997) highlighted the role of attitude towards external world and stressed on the role of culture and its effect on forming our life and feelings. Brown (2001) believes that some emotional factors such as feeling, self, and relationships in community, contribute to the concept of attitude. There are also claims that consider attitude as an evaluative reaction to some referent or attitude as an object has its roots on the individuals' beliefs or opinions about the referent (Gardner, 1985). Some other scholars believe that attitude is the state of readiness to respond to a situation and an inclination to behave in a consistent manner towards an object (Eveyik, 1999).

So as to get a more profound knowledge into the minds of learners, there is not any surer path than to think about their beliefs and attitudes. So in the arena of language teaching and learning, there has been an expanding accentuation on the study of styles and variables used by learners. At the point when learners venture in a classroom, they bring all their identity components including their beliefs, states of mind, and language styles to the learning 
environment. All of the researchers compromise that success of individuals in taking in a language successfully is precisely and straightforwardly affected by what they think and how they assess the target language, the target speakers, society, and obviously, the learning setting. In spite of the fact that just examining the states of mind and thinking of learners may not ensure any achievement, there can be the rules for the following steps taken, as learners are assumed to be the indispensable part in any learning environment.

Studies have revealed that when learners are instructed in learning strategies and afforded considerable encouragement, feedback, and opportunities to apply them, they would better process information and improve their ability to learn. Bachman (2002) claims that some learners are faced with difficulty while trying to embed strategy use in their learning schema.

In this case, there should be differentiation of strategy teaching, with some learners requiring more scaffolding, individualized, and intensive instruction than others. According to Wellman (1985), metacognition has been identified as a significant factor that affects learning. It refers to higher order thinking which involves active control over the cognitive process engaged in learning and it can also be simply defined as thinking about thinking or a person's cognition about cognition.

Metacognitive learning strategies used to oversee, regulate or self-direct language learning. They involve various processes as planning, prioritizing, setting goals, and self-management.

In Bachman's (2002) points of view explicit teaching of cognitive and meta-cognitive strategies increases learners' ability to learn and those with obvious learning problems can improve their learning through strategy learning. As indicated by Brown (2007), meta-cognitive methods are utilized for getting ready for learning, considering the learning procedure as it is occurring, observing of one's production or comprehension, and assessing learning. Directed attention, comprehension monitoring, real-time assessment, comprehension evaluation, and selective attention are among different meta-cognitive strategies suggested via his studies.

In a study regarding the effect of different types of strategy training, including meta-cognitive, cognitive, and socio-affective strategies on different language skills, O'Malley (1987) revealed that these strategies had a significant effect on the speaking skill; however, training these strategies did not significantly affect the listening skill. According to McIntyre and Noels (1996), teachers can motivate their students by showing them how and when to make use of learning strategies to improve their learning process. Teachers are supposed to show their students how effective strategy use can be through successful experiences.

Relying on the brief review of the literature on the issue and considering the importance of explicit teaching of metacognitive strategy and attitude towards foreign language the present study aimed at examining the role of explicit teaching of metacognitive strategies on collocation learning among Ardabil EFL learners as having positive and negative attitudes towards English language learning. 


\section{Methodology}

\subsection{Participants}

Using cluster sampling method, 90 Azeri EFL learners (20-25 years old) of English at upper-intermediate level from 20 different language institutes in Ardabil City participated in this study. Of them, 75 learners were selected based on the scores obtained from Attitude/Motivation Test Battery (AMTB) (1985), and a TOEFL proficiency test. Forty of them were identified as having positive attitude $(+\mathrm{A})$ and the 35 participants as having negative attitude (-A) towards English language. The participants, then, were randomly assigned into two experimental groups ( $+\mathrm{A}$ and $-\mathrm{A}$ individuals) and control groups $(+\mathrm{A}$ and -A individuals). The homogeneity of the participants was examined by a piloted TOEFL proficiency test. All of the participants were quite proficient in both Persian and Azeri-Turkish languages and they were learning English as their foreign language.

\subsection{Instrumentation}

The homogeneity of the participants at upper-intermediate level was determined by an available version of piloted paper-based TOEFL (PBT) test. This test consisted of three sections including the listening part (50 items), the grammar and written expressions (40 items), and the reading comprehension and vocabulary (50 items). The sum of correct answers determined the total score of each individual.

Gardner's Attitude/Motivation Test Battery (AMTB) (1985) was used to distinguish the learners who have positive or negative attitudes towards foreign language learning.

A 40-multiple-choice-item test adapted from English Collocation in Use by Michael McCarthy and Felicity O'Dell (2005) was conducted as the pretest and the posttests following the treatment.

\subsection{Procedure}

A version of the TOEFL (PBT) proficiency test was piloted in a group of 30 participants. The test was then administered to 90 Iranian EFL learners (20-25 years old) who were determined as upper-intermediate learners. Based on the scores obtained from the test, seventy-five participants were selected as the main participants of the study. An attempt was, then, made to discriminate positive and negative attitude learners. The Attitude/Motivation Test Battery was employed to distinguish the $+\mathrm{A}$ and $-\mathrm{A}$ attitude participants which resulted in $40+\mathrm{A}$ and 35 -A language attitude participants. The participants, then, were randomly assigned into two experimental groups $(20+\mathrm{A}$ and $20-\mathrm{A})$ and control groups $(20+\mathrm{A}$ and $15-\mathrm{A})$. Participants took part in a piloted test of collocations before the beginning of the treatment. The experimental group received an explicit teaching of metacognitive strategies as the treatment plus explicit teaching of collocations based on the course book. The control group received the same instruction and materials minus the treatment. Following 4 weeks of treatment (for 8 sessions), the piloted collocation posttest was administered to both the experimental and control groups. The pre- and posttests, two similar piloted collocation tests, were given to the participants in both experimental and control groups. The pretest was conducted one week 
prior to the treatment including 40 multiple-choice items of English collocations. Similarly, posttest was also taken by the participants with the same number of items and the same format which was administered right after the treatment to both the experimental and control groups. The obtained data were plugged into SPSS software version 20. The results are presented in the subsequent sections.

\section{Data Analysis and Results}

\subsection{Normality and Homogeneity Tests}

In the present study the relative effect of metacognitive strategies in terms of vocabulary learning, particularly the retention of collocations was investigated among Iranian Azeri-Turkish EFL learners along with their attitude towards English language. Following is an account of the findings based on the obtained results including assumptions of normality tests, homogeneity of variances, Two-Way ANOVA, and the descriptive statistics.

Table 1. Normality test

\begin{tabular}{|c|c|c|c|c|c|c|c|c|}
\hline \multicolumn{2}{|c|}{ Group } & N & \multicolumn{2}{c|}{ Skewedness } & \multicolumn{4}{c|}{ Kurtosis } \\
\cline { 3 - 10 } & Statistic & Statistic & Std. Error & Ratio & Statistic & Std. Error & Ratio \\
\hline \multirow{3}{*}{ Experimental } & Pretest & 40 & .25 & .37 & 0.67 & -.41 & .73 & -0.56 \\
\cline { 2 - 10 } & Posttest & 40 & .07 & .37 & 0.18 & -.88 & .73 & -1.20 \\
\cline { 2 - 10 } & Proficiency & 40 & -.16 & .37 & -0.43 & -1.29 & .73 & -1.76 \\
\hline \multirow{5}{*}{ Control } & Pretest & 35 & .27 & .39 & 0.67 & -.95 & .77 & -1.22 \\
\cline { 2 - 10 } & Posttest & 35 & .37 & .39 & 0.93 & -.79 & .77 & -1.02 \\
\cline { 2 - 10 } & Proficiency & 35 & -.25 & .39 & -0.62 & -1.18 & .77 & -1.52 \\
\hline
\end{tabular}

Table 1 shows the ratios of skewedness and kurtosis over their respective standard errors within the ranges of +/- 1.6. Therefore, the assumption of normality is met. A two-way ANOVA was run to compare the mean scores on the TOEFL test of the participants' positive or negative attitudes in experimental and control groups in order to ensure that the groups enjoyed the same level of general language proficiency prior to the main study. Before discussing the main results, as shown in Table 2, it should be mentioned that the groups enjoyed homogeneous variances (Levene's $F=.38, p>.05$ ).

Table 2. Levene's test of equality of error variances

\begin{tabular}{|c|c|c|c|}
\hline $\mathrm{F}$ & $\mathrm{df1}$ & $\mathrm{df} 2$ & Sig. \\
\hline .38 & 3 & 71 & .76 \\
\hline
\end{tabular}


Table 3. A two-way ANOVA TOEFL test by group and attitude

\begin{tabular}{|c|c|c|c|c|c|c|}
\hline Source & $\begin{array}{c}\text { Type III Sum of } \\
\text { Squares }\end{array}$ & Df & Mean Square & F & Sig. & $\eta^{2}$ \\
\hline Group & 1.10 & 1 & 1.10 & .17 & .67 & .002 \\
\hline Attitude & 10.98 & 1 & 10.98 & 1.71 & .19 & .024 \\
\hline Group * Attitude & .57 & 1 & .57 & .09 & .76 & .001 \\
\hline Error & 454.53 & 71 & 6.40 & & & \\
\hline Total & 12273.00 & 75 & \multicolumn{3}{|l}{} \\
\hline
\end{tabular}

According to Table 3, the statistics does not show any significant difference between the experimental and control groups on the TOEFL test $(F(1,71)=.17, p>.05, \eta 2=.002)$ meaning that the experimental and control groups enjoyed the same level of general language proficiency prior to the main study. The statistics does not even show any significant difference between the $+\mathrm{A}$ and $-\mathrm{A}$ participants on the TOEFL test $(F(1,71)=1.71, p>.05$, $\eta 2=.024)$ meaning that the $+\mathrm{A}$ and $-\mathrm{A}$ participants enjoyed the same level of general language proficiency prior to the main study. There was not any significant interaction between groups and attitude on the proficiency test $(F(1,71)=.09, p>.05, \eta 2=.001)$. However, considering the descriptive statistics, +A participants - both experimental and control groups - showed slightly higher means than the -A participants.

\subsection{Pretest of Collocation}

A two-way ANOVA was run to compare the $+\mathrm{A}$ and $-\mathrm{A}$ experimental and control groups mean scores on the pretest of collocations test in order to ensure that the groups enjoyed the same level of knowledge on recalling of collocations prior to the main study. Before discussing the main results, Levene's test of equality of error variances showed that the groups enjoyed homogeneous variances $(\mathrm{F}=.45, \mathrm{p}>.05)$.

Table 4. Two-way ANOVA pretest on recalling collocations by group and attitude

\begin{tabular}{|c|c|c|c|c|c|c|}
\hline Source & $\begin{array}{c}\text { Type III Sum of } \\
\text { Squares }\end{array}$ & Df & $\begin{array}{c}\text { Mean } \\
\text { Square }\end{array}$ & F & Sig. & $\eta^{2}$ \\
\hline Group & 2.49 & 1 & 2.49 & .96 & .33 & .01 \\
\hline Attitude & 1.01 & 1 & 1.01 & .39 & .53 & .005 \\
\hline Group * Attitude & 3.42 & 1 & 3.42 & 1.32 & .25 & .01 \\
\hline Error & 183.52 & 71 & 2.58 & & \\
\hline Total & 15058.00 & 75 & \multicolumn{5}{|l}{} \\
\hline
\end{tabular}

As shown in Table 4, there was not any significant difference between the experimental and control groups on the recalling of collocations test $(F(1,71)=.96, p>.05, \eta 2=.01)$ 
meaning that the experimental and control groups enjoyed the same level of knowledge on recalling of collocations prior to the main study. There was not any significant difference between the $+\mathrm{A}$ and $-\mathrm{A}$ participants on the pretest of recalling of collocations test $(F(1,71)$ $=.39, p>.05, \eta 2=.005)$ meaning the $+\mathrm{A}$ and $-\mathrm{A}$ participants enjoyed the same level of knowledge on recalling of collocations prior to the main study $(+A: M=14.16, S E=.24$; $-A$ : $M=13.93, S E=.28)$. There was not any significant interaction between groups and attitude on the pretest of recalling of collocations test $(F(1,71)=1.32, p>.05, \eta 2=.01)$. However, -A participants - both experimental and control groups - showed slightly higher means than the +A participants.3.3 Posttest of Collocation

A two-way ANOVA was run to compare the mean scores of the $+\mathrm{A}$ and $-\mathrm{A}$ participants in experimental and control groups on the posttest of recalling of collocations test in order to examine the effect of explicit teaching of metacognitive strategies on subjects (+A and $-\mathrm{A})$ recalling of collocations and which attitude type benefited more from the instructions. Before discussing the main results, it should be mentioned that the groups enjoyed homogeneous variances (Levene's test of equality of error variances: $F=1.02, p>.05$ ). Thus the results of the two-way ANOVA can be discussed.

Table 5. Two-way ANOVA posttest on recalling collocations by group and attitude

\begin{tabular}{|c|c|c|c|c|c|c|}
\hline Source & $\begin{array}{c}\text { Type III Sum of } \\
\text { Squares }\end{array}$ & Df & $\begin{array}{c}\text { Mean } \\
\text { Square }\end{array}$ & F & Sig. & $\eta^{2}$ \\
\hline Group & 144.45 & 1 & 144.45 & 56.79 & .00 & .44 \\
\hline Attitude & 60.89 & 1 & 60.89 & 23.94 & .00 & .25 \\
\hline Group*Attitude & 3.51 & 1 & 3.51 & 1.38 & .24 & .01 \\
\hline Error & 180.60 & 71 & 2.54 & & \\
\hline Total & 19024.00 & 75 & & & \\
\hline
\end{tabular}

The results show a significant difference between the experimental and control groups on the posttest of recalling of collocations test $(F(1,71)=56.79, p<.05, \eta 2=.44)$, representing a large effect size. Therefore, explicit teaching of metacognitive strategies significantly affected $+\mathrm{A}$ and -A EFL students' recalling of collocations. The statistics also shows a significant difference between the $+\mathrm{A}$ and $-\mathrm{A}$ participants on the posttest of recalling collocations test $(F$ $(1,71)=23.94, p<.05, \eta 2=.25)$ representing a large effect size. Accordingly, the $+\mathrm{A}$ subjects $(M=16.47, S E=.24)$ benefited more from the explicit teaching of metacognitive strategies than their -A counterparts $(M=14.65, S E=.27)$. On the other hand, the statistics does not show any significant interaction between groups and attitude types on the posttest of recalling of collocations test $(F(1,71)=1.38, p>.05, \eta 2=.019)$ representing a weak effect size. However, the + A participants of the experimental group $(M=18.09, S E=.34)$ obtained higher means than the -A participants $(M=15.83, S E=.37)$. 


\subsection{Criterion Related Validity}

The Pearson correlation coefficient between the TOEFL test and pretest and posttest of recalling collocations was calculated as indices of validity for the latter two tests.

Table 6. Pearson correlation of the TOEFL test, pretest, and posttest on recalling collocations

\begin{tabular}{|c|c|c|}
\hline & & Proficiency \\
\hline \multirow{3}{*}{ Pretest } & Pearson Correlation & $.873^{* *}$ \\
\hline & Sig. (2-tailed) & .000 \\
\hline & $\mathrm{N}$ & 75 \\
\hline \multirow{3}{*}{ Posttest } & Pearson Correlation & $.523^{* *}$ \\
\hline & Sig. (2-tailed) & .000 \\
\hline & $\mathrm{N}$ & 75 \\
\hline \multicolumn{3}{|c|}{$* *$ Correlation is significant at the 0.01 level (2-tailed). } \\
\hline
\end{tabular}

Based on the results displayed in Table 6 , it can be concluded that both pretest $(r(73)=.87$, $p<.05)$ and posttest $(r(73)=.52, p<.05)$ enjoyed significant validity.

Table 7. K-R 21 reliability indices

\begin{tabular}{|c|c|c|c|c|}
\hline & $\mathrm{N}$ & Mean & Variance & K-R21 \\
\hline $\begin{array}{c}\text { TOEFL } \\
\text { pilot }\end{array}$ & 30 & 108.96 & 211.89 & 0.79 \\
\hline Pilot1 & 30 & 29.66 & 24.78 & 0.81 \\
\hline Pilot2 & 30 & 19.46 & 40.05 & 0.75 \\
\hline Pretest & 75 & 14.050 & 41.29 & 0.89 \\
\hline Posttest & 75 & 15.56 & 26.59 & 0.81 \\
\hline TOEFL & 120 & 103.72 & 31.69 & 0.84 \\
\hline
\end{tabular}

The K-R21 reliability indices for the TOEFL pilot, pilot tests 1 and 2, pretest and posttest of recalling collocations, and the TOEFL test are $.79, .81, .75, .89, .81$ and .84 , respectively.

\section{Discussion and Conclusion}

The findings of the present study revealed that explicit teaching of metacognitive strategies had a significant effect on both + A and -A EFL students' recalling of collocations. Secondly, the results showed that explicit teaching of metacognitive strategies does not have the same effect on $+\mathrm{A}$ and $-\mathrm{A}$ students' recall of collocations, as $+\mathrm{A}$ participants of the study outperformed the $-\mathrm{A}$ ones. 


\section{Mll Macrothink}

International Journal of English Language Education

ISSN 2325-0887

2016, Vol. 4, No. 1

Though teaching metacognitive strategies to the second language learners of English has recorded invaluable supports, there are some researches the results of which minimize the usage of such strategies and shed doubts on their effectiveness, or at least on their applicability in certain proficiency levels. Mizumoto (2010) stressed the effect of explicit teaching of learning strategies for the enhancement of vocabulary knowledge of the learners; meanwhile, he mentions that "the learners with average proficiency level do not employ the metacognitive strategies" (p.130). Aside from vocabulary, other language components and skills were found to be positively affected by metacognitive strategies. Writing (Wenden, 1991), speaking (Chamot \& Kupper, 1989), listening comprehension (O'Malley, Chamot \& Küpper, 1989; Vandergrift, 2002), and reading comprehension (Pressley, Borkowski \& Schneider, 2010; Sen, 2012) are some of the investigated skills.

The findings of the present study revealed that $+\mathrm{A}$ students outperformed the $-\mathrm{A}$ students in retention of collocations following metacognitive strategy training. But this difference was not statistically significant.

Foreign language learners need to know how to study in such a way so that they can learn language effectively. Some learners are dependent on instructors and others, or on a structured language program to tell them what to do and how to ponder in their objectives. But good language learners develop metacognitive skills which enable them to deal with their own particular learning; therefore they are less dependent on others or on the changes that may occur in learning situation (Griffiths, 2006).

While it is essential to learn from a good teacher via a thought-through language program, it is perhaps even more significant for these learners to have a meaningful learning process. We cannot teach everything just by good teachers and organizes programs. Going beyond what teachers and programs provide and developing the kind of meta-cognitive behavior are what students need to do so that they can deal with their own way of learning effectively.

A theoretical framework of strategies used for language learning and language use suggested by Macaro (2006) offers a possible relationship between strategy use and second language learning success.

The effectiveness of explicit instruction of vocabulary learning strategies with Japanese EFL university students was investigated in Mizumoto and Takeuchi (2009) study. They found if students get to know these strategies, their second language vocabulary will increase profoundly. A study was directed by Eslami-Rasekh and Ranjbari (2003) on the training of metacognitive strategies. The consequences of their study demonstrated beneficial outcomes of explicit metacognitive strategy training on the vocabulary learning among Iranian EFL learners.

Mardani and Moinzadeh (2011) conducted another study to investigate the effect of explicit training of metacognitive vocabulary learning strategies among Iranian female advanced EFL learners to understand how they recall the related idioms. Positive effects related to short term and long term participants' recall of idioms was reported. 


\section{Macrothink}

Based on the findings of Lajooee and Barimani (2013) in a contrastive study on explicit learning of vocabulary via role-play and memorization among Iranian EFL female learners, the positive effect of explicit teaching of metacognitive strategies on vocabulary learning was observed.

\section{References}

Assaf, A. S. (2001). Palestinian students' attitudes towards Modern Standard Arabic and Palestinian City Arabic. RELC Journal, 32(2), 45-62. http://dx.doi.org/10.1177/003368820103200204

Bachman, P. (2002). Strategy instruction. ERIC Identifier, No. ED 474302.

Balcazar, I. H. (2003). Language Shift and Language Attitudes of Kaqchikel Maya Adolescents. Paper presented at the 4th International Symposium on Bilingualism, Arizona State University.

Bernaus, M., Masgoret, A. M., Gardner, R. C., \& Reyes, E. (2004). Motivation and attitudes towards learning languages in multicultural classrooms. The International Journal of Multilingualism, 1(2), 75-89. http://dx.doi.org/10.1080/14790710408668180

Brown, H. D. (2001). Teaching by principles: An interactive approach to language pedagogy (2nd ed.). San Francisco Public University.

Brown, D. H. (2007). Principles of language learning and teaching (5th ed.). Pearson: Longman.

Chamot, A. U., \& Kupper, L. (1989). Learning strategies in foreign language instruction. Foreign Language Annals, 22(1), 13-22. http://dx.doi.org/10.1111/j.1944-9720.1989.tb03138.x

Choy, S. C., \& Troudi, S. (2006). An investigation into the changes in perceptions of and attitudes towards learning English in a Malaysian college. International Journal of Teaching and Learning in Higher Education, 18(2), 120-130.

Eslami-Rasekh, Z., \& Ranjbari, R. (2003). Metacognitive strategy training for vocabulary learning. TESL EJ, 7(2), 5-15.

Eveyik, E. (1999). Boğaziçi Üniversitesi Sosyal Bilimler Enstitüsü. Basılmamış Yüksek Lisans Tezi. [Development of an Attitude Scale to Investigate Turkish EFL Teachers' Attitudes]. İstanbul.

Feng. R., \& Chen, H. (2009). An analysis on the importance of motivation and strategy in postgraduates English acquisition. English Language Teaching. 2(2), 93-97. http://dx.doi.org/10.5539/elt.v2n3p93

Flaitz, J. (1988). The ideology of English: French perceptions of English as a world language. Berlin: Mouton de Gruyter. http://dx.doi.org/10.1515/9783110848120 


\section{$\Lambda$ Macrothink}

Gan, Z. (2004). Attitudes and strategies as predictors of self-directed language learning in an EFL context. International Journal of Applied Linguistics, 14(3), 389-411. http://dx.doi.org/10.1111/j.1473-4192.2004.00071.x

Gardner, R. C. (1985). Social psychology and second language learning: The role of attitudes and motivation. London: Edward Arnold.

Gibb, M. (1999). A comparative study of attitudes towards varieties of English held by professionals and tertiary level students in Korea. The Korea TESOL Journal, 2(1), 31-51.

Graham, S. J. (2004). Giving up on modern foreign languages? Students' perceptions of learning French. The Modern Language Journal, 88(2), 171-191. http://dx.doi.org/10.1111/j.0026-7902.2004.00224.x

Griffiths, C. (2006). Strategy development and progress in language learning. Prospect, 21(3), $58-76$.

Kara, A. (2009). The effect of a 'learning theories' unit on students' attitudes towards learning. Australian Journal of Teacher Education, 34(3), 100-113. http://dx.doi.org/10.14221/ajte.2009v34n3.5

Karstadt, A. (2002). Standard Englishes: What do American undergraduates think? English Today, 18(3), 38-45. http://dx.doi.org/10.1017/S0266078402003061

Kiptui, D. K., \& Mbugua, Z. K. (2009). Factors that contribute to poor academic achievement in English in Kerio Valley schools. Kenya Journal of Educational Management, 1(2), 1-15.

Kırımsoy K. D. (1997). Anadili Öğretiminde BilişselGiriş Özelliklerive Duyuşsal Giriş Davranışlarını Geliştirmeye Yönelik Etkinlikler. [Introduction to Cognitive and Affective Characteristics of Native Education Check-in Activities to Improve Behavior.] Journal of Language, November, Issue, 61, Ankara.

Lajooee, E., \& Barimani, Sh. (2013). Contrastive study on learning vocabulary through role-play and memorization among EFL female learners. Journal of Academic and Applied Studies, 3(1), 1-19.

Lee, J. F. K. (2001a). Attitudes towards debatable usages among English language teachers and students. Journal of Applied Linguistics, 6(2), 1-21.

Lee, J. F. K. (2001b). Teachers' attitudes towards disputable usages. RELC Journal, 32(2), 115. http://dx.doi.org/10.1177/003368820103200201

Levine, G. S. (2003). Student and instructor beliefs and attitudes about target language use, first language use and anxiety: Report of a questionnaire study. The Modern Language Journal, 87(3), 343-364. http://dx.doi.org/10.1111/1540-4781.00194

Lindemann, S. (2002). Listening with an attitude: A model of native-speaker comprehension of non-native speakers in the United States. Language in Society, 31(3), 419-441. http://dx.doi.org/10.1017/S0047404502020286 


\section{Macrothink}

International Journal of English Language Education

ISSN 2325-0887

2016, Vol. 4, No. 1

Macaro, E. (2006). Strategies for language learning and for language use: Revising the theoretical framework. The Modern Language Journal, 90(3), 320-337. http://dx.doi.org/10.1111/j.1540-4781.2006.00425.x

McIntyre, P. D., \& Noels, K. A. (1996). Using social psychological variables to predict the use of language learning strategies. Foreign Language Annals, 29(2), 373-386. http://dx.doi.org/10.1111/j.1944-9720.1996.tb01249.x

Mardani, M., \& Moinzadeh, A. (2011). The effect of explicit training of metacognitive vocabulary learning strategies on recall and retention of idioms by advanced EFL students. Iranian EFL Journal, 7(3), 117-131.

Marley, D. (2004). Language attitudes in Morocco following recent changes in language policy. Language Policy, 3(2), 25-46. http://dx.doi.org/10.1023/B:LPOL.0000017724. 16833.66

McCarthy, M., \& O'Dell, F. (2005). English collocations in use. Cambridge: Cambridge University Press.

Mizumoto, A. (2010). Exploring the art of vocabulary learning strategies: A closer look at Japanese EFL university students. Tokyo: Kinseido.

Mizumoto, A., \& Takeuchi, O. (2009). Examining the effectiveness of explicit instruction of vocabulary learning strategies with Japanese EFL university students. Language Teaching Research, 13(4), 425-449. http://dx.doi.org/10.1177/1362168809341511

O'Malley, J. M. (1987). The effects of training in the use of learning strategies. In D. Nunan, (Ed), Second language teaching and learning (pp. 120-139). Boston, Massachusetts: Heinle and Heinle Publishers.

O'Malley, J. M., Chamot, A. U., \& Küpper, L. (1989). Listening comprehension strategies in second language acquisition. Applied Linguistics, 10(4), 418-437. http://dx.doi.org/10.1093/ applin/10.4.418

Popham, W. J. (2011). Classroom assessment: What teachers need to know? Boston, MA: Pearson.

Pressley, M., Borkowski, J. G., \& Schneider, W. (2010). Cognitive strategies: Good strategy users coordinate metacognition and knowledge. Annals of Child Development, 4(2), 89-129.

Sakui, K., \& Gaies, S.J. (1999). Investigating Japanese learners' beliefs about language learning. System, 27(2), 473-492. http://dx.doi.org/10.1016/S0346-251X(99)00046-9

Schmidt, D., Inbar, S. O., \& Shohamey, E. (2004). The effects of teaching spoken Arabic on Students' attitudes and motivation in Israel. The Modern Language Journal, 88(2), 217-228. http://dx.doi.org/10.1111/j.0026-7902.2004.00226.x

Sen, N. S. (2012). The affordances of mobile technologies in developing collaborative reading comprehension strategies through metacognitive instruction. INTED Proceedings, 6(3), 3840-3840. 
Starks, D., \& Paltridge, B. (1994). Varieties of English and the EFL classroom: A New Zealand study. The TESOLANZ Journal, 2(3), 69-77.

Triandis, H. C. (1971). Attitudes and attitude change. New York: Wiley.

Vandergrift, L. (2002). It was nice to see that our predictions were right: Developing metacognition in L2 listening comprehension. Canadian Modern Language Review, 58(4), 555-575. http://dx.doi.org/10.3138/cmlr.58.4.555

Walqui, A. (2000). Access and engagement: Program design and instructional approaches for immigrant students in secondary schools. McHenry, IL, and Washington D. C.: Delta Systems and Center for Applied Linguistics.

Wellman, H. M. (1985). The origins of metacognition. In D. L. Forest-Pressley, G. MacKinnon, and T. Waller (Eds.), Metacognition, cognition and human performance (pp. 120). Theoretical Perspectives, Academic Press: New York. PMCid:PMC369098

Wenden, A. (1991). Learner strategies for learner autonomy. London: Prentice-Hall. PMid:1915591

White, C. M. (2002). Language authenticity and identity: Indigenous Fijian students and language use in schools. Language, Culture and Curriculum, 15(1), 16-29. http://dx.doi.org/10.1080/07908310208666630

Williams, M., Burden, R., \& Lanvers, U. (2002). French is the language of love and stuff: Student perceptions of issues related to motivation in learning a foreign language. British Educational Research Journal, 28(4), 503-528. http://dx.doi.org/10.1080/0141192022000005805

Yang, A., \& Lau, L. (2003). Student attitudes to the learning of English at secondary and tertiary levels. System, 31(1), 107-123. http://dx.doi.org/10.1016/S0346-251X(02)00076-3

Zhou, M. (2002). The spread of Putonghua and language attitude changes in Shanghai and Guangzhou China. Journal of Asian Pacific Communication, 11(2), 231-253. http://dx.doi.org/10.1075/japc.11.2.07zho

\section{Copyright Disclaimer}

Copyright for this article is retained by the author(s), with first publication rights granted to the journal.

This is an open-access article distributed under the terms and conditions of the Creative Commons Attribution license (http://creativecommons.org/licenses/by/3.0/). 